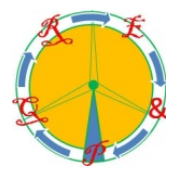

\title{
How important are ports for the offshore wind industry?: the case of Spain
}

\author{
A. Filgueira-Vizoso ${ }^{1}$, F. Puime-Guillén ${ }^{2}$, D. Cordal-Iglesias ${ }^{3}$, A.I. García-Diez ${ }^{4}$, I. Lamas-Galdo 5 \\ and L. Castro-Santos ${ }^{6}$ \\ ${ }^{1}$ Universidade da Coruña, Departamento de Química, Escola Politécnica Superior, Esteiro, 15471 Ferrol, Spain, Phone \\ number: +34 881013289, e-mail: almudena.filgueira.vizoso@udc.es \\ ${ }^{2}$ Universidade da Coruña, Departamento de Empresa, Facultade de Economía e Empresa, Elviña, 15071 Ferrol, Spain \\ Phone number: +34 881012453, e-mail: felix.puime@udc.es \\ ${ }^{3}$ Universidade da Coruña, Escola Politécnica Superior, Esteiro, 15471 Ferrol, Spain, Phone number: +34881013395 , \\ e-mail: david.cordal@udc.es \\ ${ }^{4}$ Universidade da Coruña, Departamento de Enxeñaría Naval e Industrial Escola Politécnica Superior, Esteiro, 15471 \\ Ferrol, Spain, Phone number: +34 881013221, e-mail: ana.gdiez@udc.es \\ ${ }^{5}$ Universidade da Coruña, Departamento de Ciencias da Navegación e Enxeñaría Mariña, Escola Politécnica Superior, \\ Esteiro, 15471 Ferrol, Spain, Phone number: +34 881013896, e-mail: isabel.lamas.galdo@udc.es \\ ${ }^{6}$ Universidade da Coruña, Departamento de Enxeñaría Naval e Industrial Escola Politécnica Superior, Esteiro, 15471 \\ Ferrol, Spain, Phone number: +34 881013890, e-mail: laura.castro.santos@udc.es
}

\begin{abstract}
Offshore wind is becoming a new technology to develop a better sustainable world. Its progress is linked to the use of port facilities, where the offshore wind farms can be stored or pre-installed. The aim of this paper is to analyse the storage space availability for ports in terms of being used for the new offshore wind sector. The case of study will be focused on analysing the port facilities in Spain, country with a great offshore wind resource in some specific areas. Results indicate the ports that can be used for the development of offshore wind in Spain. This work is important in order to establish a roadmap of the offshore wind business in Spain, which can repair the economic and social damaged due to SARS-CoV-2 pandemic.
\end{abstract}

Key words. offshore wind, offshore renewable energies, port, crane, surface.

\section{Introduction}

In the 90s there was an interest in the analysis of atmospheric pollution, trying to quantify and reduce the gases that modified the greenhouse effect. These gases are known as Greenhouse Gases (GHG) that cause global warming of the planet. In order to avoid global warming caused by anthropogenic causes, the well-known Kyoto Protocol was created in 1997 in Kyoto (Japan) [1]. This protocol has achieved that the governments that joined it established laws and policies to meet environmental objectives, that companies take the environment into account when making investment decisions and promote the creation of the carbon market, whose purpose is to achieve the reduction of emissions at the lowest cost. This was the starting point for GHG reduction [2,3], which was followed by numerous protocols and agreements. The last agreement was carried out in 2016 in Paris [4] and it was agreed that the increase in the temperature of the planet could not exceed $1.5^{\circ}$ and for this in 2030 the GHG reductions should be $45 \%$ lower than in 2010 and in 2050 to achieve zero net emissions. To achieve these objectives it is necessary to modify the way of obtaining energy, going from the use of fossil fuels to the use of renewable energies [5].

In this context, renewable energy sources have been used on the planet for different uses during centuries: agriculture, livestock, etc., but always in small farms. Nowadays, this use of renewable and inexhaustible energy needs to be done through power plants that supply energy in a great way.

This transition towards an energy system based on renewable technologies will have very positive economic effects for the global economy and development. According to IRENA (International Renewable Energy Agency) [6], reaching the Paris Agreement [4] requires doubling the share of renewable energy in electricity generation to $57 \%$ worldwide by 2030 . This requires increasing annual investments in renewable energy from 330 billion dollars today up to 750 billion dollars, with 
the consequent boost to job creation and growth linked to the green economy [7].

Within renewable energies, one of the ones that is taking the largest market is wind energy and as it is known, 70\% of our planet is water, so it is not a mistake to think that most of the development of wind energy will take place through offshore wind farms.

This energy source has been introduced to the market through modern wind turbines in the 1980s [8], and the energy generated by each turbine has ranged from $450 \mathrm{~kW}$ in the world's first wind farm (Towards 2000 [9]) in the United States to General Electric's Haliade X wind turbine with $12 \mathrm{MW}$ power [10].

This increase in the power of the turbines is associated with the sizes of all associated equipment: rotor, nacelle and substructure, reaching today heights of $260 \mathrm{~m}$ for the Haliade-X12MW, with rotor sizes of $220 \mathrm{~m}$ and a swept area of $36,000 \mathrm{~m}^{2}$ [10].

Due to the sizes mentioned, these megastructures need to be manufactured in locations where road transport is minimal or null, since the most common way of transporting equipment for offshore installation is via barges, tugboats and other special vessels.

Regarding the development of offshore wind installation and maintenance, characteristics of ports and shipyards should be studied.

The layout of the installation port is an important issue in the offshore wind industry [11-13]. In this sense, several authors explain some aspects about it [14]. Akbari et al. [15] explain that the storage space availability, as part of a port's layout, as an importance of 0.289 under 1 regarding the criteria to select an installation port. They have analyzed several parameters related to ports and offshore wind to be installation port or maintenance port, such as: seabed suitability, component handling, quay length, quay load, port's depth, distance to offshore site, distance to key component supplier, distance to road, potential for expansion, component laydown area availability, storage and component fabrication facility. The storage space availability is crucial for the case of an installation port. Therefore, the aim of this paper is to analyze the storage space availability for the Spanish ports in terms of being used for the new offshore wind sector.

\section{Methodology}

The proposed method will be developed in the following steps:

- Calculate the number of offshore wind platforms of each type that can fit in each port.

- Analyze the most representative ports in Spain.

- Calculate the useful surface of the ports.

- Calculate the area occupied by each of the wind turbines.

- Divide the useful area of the port between the area of the wind turbines, taking into account the necessary spaces for their handling.

To calculate the surface of the platforms it has been simplified as follows: WindFloat and Zhizin Zhao Design have been simplified as a circle and for the NREL Spar and DTU as a rectangle

The work scenarios are as follows:
- Scenario 1 (S1): Semi-submersible WindFloat Platform with 5MW NREL turbine

- Scenario 2 (S2): NREL Spar platform with 5MW NREL turbine

- Scenario 3 (S3): ZHIZIN ZHAO DESIGN Semisubmersible platform with 10MW DTU turbine

- Scenario 4 (S4): DTU Spar platform with 10MW DTU turbine

Table I. Areas of platforms and turbines

\begin{tabular}{|c|c|c|c|}
\hline $\mathrm{S}$ & $\begin{array}{c}\text { platform } \\
\text { AREA }\left(\mathrm{m}^{2}\right)\end{array}$ & $\begin{array}{c}\text { TURBINE } \\
\text { AREA }\left(\mathrm{m}^{2}\right)\end{array}$ & $\begin{array}{c}+50 \% \text { maneuve- } \\
\text { rability }\left(\mathrm{m}^{2}\right)\end{array}$ \\
\hline $\mathrm{S} 1$ & 4.536 & 858 & 2.697 \\
\hline $\mathrm{S} 2$ & 1.128 & 858 & 993 \\
\hline $\mathrm{S} 3$ & 9.840 & 1.931 & 5.885 \\
\hline $\mathrm{S} 4$ & 1.440 & 1.931 & 1.685 \\
\hline
\end{tabular}

Considering Table I, the total Surface in $\mathrm{m} 2$ is shown in Table II.

Table II. Total area

\begin{tabular}{|c|c|}
\hline SCENARIO & TOTAL AREA $\left(\mathrm{m}^{2}\right)$ \\
\hline $\mathrm{S} 1$ & 8.092 \\
\hline $\mathrm{S} 2$ & 2.979 \\
\hline $\mathrm{S} 3$ & 17.656 \\
\hline $\mathrm{S} 4$ & 5.056 \\
\hline
\end{tabular}

Figure I shows the Spanish ports considered for this study.

Figure I. Spanish ports.

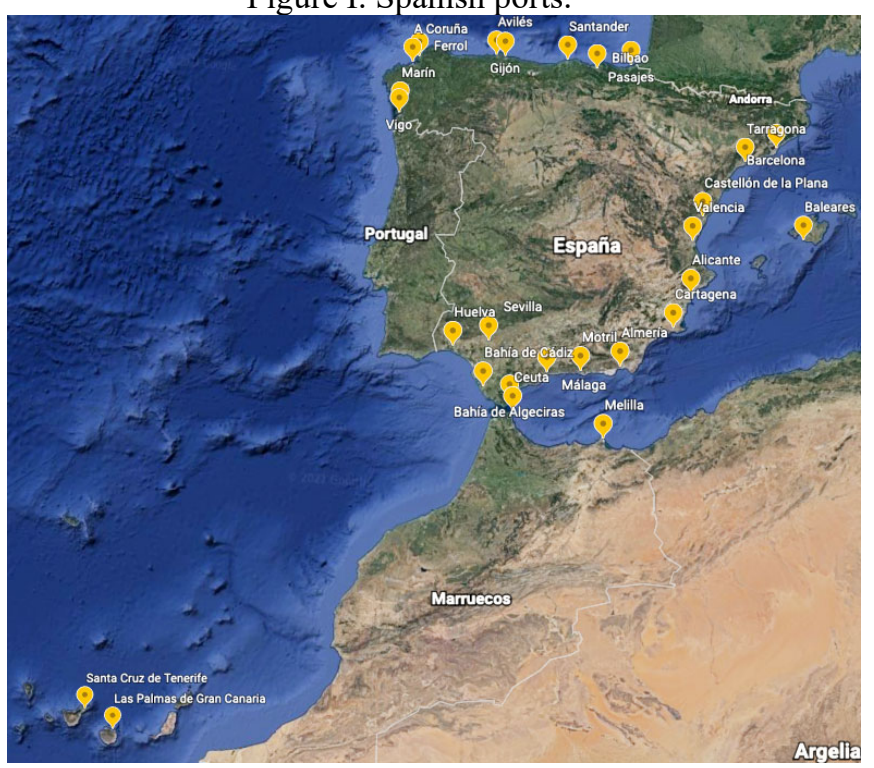


Table III shows the main Spanish ports with their main characteristics (location and uncovered area) [16-18].

Table III. Port areas [16,17]

\begin{tabular}{|c|c|c|c|}
\hline $\mathrm{N}$ & NAME & LOCATION & $\begin{array}{l}\text { UNCOVERED } \\
\text { AREA }\left(\mathrm{m}^{2}\right) \\
\end{array}$ \\
\hline 1 & A Coruña & A Coruña & 150.255 \\
\hline 2 & Alicante & Alicante & 80.795 \\
\hline 3 & Almería & Almería & 45.805 \\
\hline 4 & Avilés & Avilés & 93.155 \\
\hline 5 & $\begin{array}{l}\text { Bahía de } \\
\text { Algeciras }\end{array}$ & Algeciras & 241.390 \\
\hline 6 & Bahía de Cádiz & Cádiz & 223.000 \\
\hline 7 & Baleares & $\begin{array}{l}\text { Palma de } \\
\text { Mallorca }\end{array}$ & 247.687 \\
\hline 8 & Barcelona & Barcelona & 554.965 \\
\hline 9 & Bilbao & Bilbao & 201.420 \\
\hline 10 & Cartagena & Cartagena & 119.495 \\
\hline 11 & Castellón & Castellón & 135.500 \\
\hline 12 & Ceuta & Ceuta & 34.770 \\
\hline 13 & $\begin{array}{c}\text { Ferrol- San } \\
\text { Cibrao } \\
\end{array}$ & Ferrol & 168.580 \\
\hline 14 & Gijón & Gijón & 211.060 \\
\hline 15 & Huelva & Huelva & 857.870 \\
\hline 16 & Las Palmas & $\begin{array}{c}\text { Las Palmas } \\
\text { de GC }\end{array}$ & 251.765 \\
\hline 17 & Málaga & Málaga & 59.535 \\
\hline 18 & $\begin{array}{c}\text { Marín y Ría de } \\
\text { Pontevedra }\end{array}$ & Marín & 37.620 \\
\hline 19 & Melilla & Melilla & 13.730 \\
\hline 20 & Motril & Motril & 45.240 \\
\hline 21 & Pasaia & Pasaia & 26.500 \\
\hline 22 & $\begin{array}{c}\text { Santa Cruz de } \\
\text { Tenerife } \\
\end{array}$ & $\begin{array}{l}\text { Santa Cruz } \\
\text { de Tenerife }\end{array}$ & 111.375 \\
\hline 23 & Santander & Santander & 131.415 \\
\hline 24 & Sevilla & Sevilla & 425.000 \\
\hline 25 & Tarragona & Tarragona & 198.760 \\
\hline 26 & Valencia & Valencia & 382.110 \\
\hline 27 & Vigo & Vigo & 26.815 \\
\hline 28 & $\begin{array}{c}\text { Vilagarcía de } \\
\text { Arousa } \\
\end{array}$ & $\begin{array}{l}\text { Vilagarcía } \\
\text { de Arousa }\end{array}$ & 28.670 \\
\hline
\end{tabular}

\section{Case of study}

Spain is a country with an important wind resource and a large coastal area. It has 28 main ports $[16,17]$, being a country with great potential for the development of offshore wind energy. The platforms chosen for the study are the semi-submersible, the TLP and the spar in two different rated power: $5 \mathrm{MW}$ and $10 \mathrm{MW}$, as shown in Figure II.
Figure II. Study alternatives

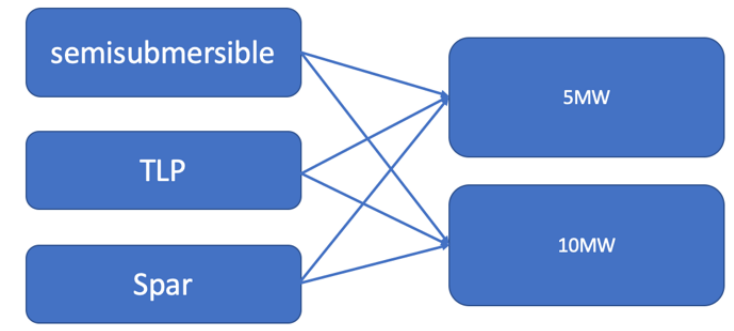

\section{Results}

Table IV, Table V, Table VI and Table VII show that the best four ports in terms of uncovered surfaces are: Huelva, Barcelona, Sevilla and Valencia.

Table IV. Number of floating offshore wind platforms and turbines in Scenario 1.

\begin{tabular}{|c|c|}
\hline $\mathrm{N}$ & S1 \\
\hline 15 & 106 \\
\hline 8 & 68 \\
\hline 24 & 52 \\
\hline 26 & 47 \\
\hline 16 & 31 \\
\hline 7 & 30 \\
\hline 5 & 29 \\
\hline 6 & 27 \\
\hline 14 & 26 \\
\hline 9 & 24 \\
\hline 25 & 24 \\
\hline 13 & 20 \\
\hline 1 & 18 \\
\hline 11 & 16 \\
\hline 23 & 16 \\
\hline 10 & 14 \\
\hline 22 & 13 \\
\hline 4 & 11 \\
\hline 2 & 9 \\
\hline 17 & 7 \\
\hline 3 & 5 \\
\hline 20 & 5 \\
\hline 12 & 4 \\
\hline 18 & 4 \\
\hline 21 & 3 \\
\hline 27 & 3 \\
\hline 28 & 3 \\
\hline 19 & 1 \\
\hline
\end{tabular}

Table V. Number of floating offshore wind platforms and turbines in Scenario 2.

\begin{tabular}{|c|c|}
\hline $\mathrm{N}$ & $\mathrm{S} 2$ \\
\hline 15 & 239 \\
\hline 8 & 155 \\
\hline 24 & 118 \\
\hline
\end{tabular}




\begin{tabular}{|c|c|}
\cline { 2 - 2 } & 106 \\
\hline 16 & 70 \\
\hline 7 & 69 \\
\hline 5 & 67 \\
\hline 6 & 62 \\
\hline 14 & 59 \\
\hline 9 & 56 \\
\hline 25 & 55 \\
\hline 13 & 47 \\
\hline 1 & 42 \\
\hline 11 & 37 \\
\hline 23 & 36 \\
\hline 10 & 33 \\
\hline 22 & 31 \\
\hline 4 & 26 \\
\hline 2 & 22 \\
\hline 17 & 16 \\
\hline 3 & 12 \\
\hline 20 & 12 \\
\hline 18 & 10 \\
\hline 12 & 9 \\
\hline 28 & 8 \\
\hline 21 & 7 \\
\hline 27 & 7 \\
\hline 19 & 3 \\
\hline & \\
\hline
\end{tabular}

Table VI. Number of floating offshore wind platforms and turbines in Scenario 3.

\begin{tabular}{|c|c|}
\hline $\mathrm{N}$ & $\mathrm{S} 3$ \\
\hline 15 & 40 \\
\hline 8 & 26 \\
\hline 24 & 20 \\
\hline 26 & 18 \\
\hline 5 & 11 \\
\hline 7 & 11 \\
\hline 16 & 11 \\
\hline 6 & 10 \\
\hline 9 & 9 \\
\hline 14 & 9 \\
\hline 25 & 9 \\
\hline 1 & 7 \\
\hline 13 & 7 \\
\hline 11 & 6 \\
\hline 23 & 6 \\
\hline 10 & 5 \\
\hline 22 & 5 \\
\hline 4 & 4 \\
\hline 2 & 3 \\
\hline 3 & 2 \\
\hline 17 & 2 \\
\hline 20 & 2 \\
\hline 12 & 1 \\
\hline 18 & 1 \\
\hline
\end{tabular}

\begin{tabular}{|l|l|}
\cline { 2 - 2 } 21 & 1 \\
\hline 27 & 1 \\
\hline 28 & 1 \\
\hline 19 & 0 \\
\hline
\end{tabular}

Table VII. Number of floating offshore wind platforms and turbines in Scenario 4.

\begin{tabular}{|c|c|}
\hline $\mathrm{N}$ & $\mathrm{S} 4$ \\
\hline 15 & 141 \\
\hline 8 & 91 \\
\hline 24 & 70 \\
\hline 26 & 62 \\
\hline 16 & 41 \\
\hline 7 & 40 \\
\hline 5 & 39 \\
\hline 6 & 36 \\
\hline 14 & 34 \\
\hline 9 & 33 \\
\hline 25 & 32 \\
\hline 13 & 27 \\
\hline 1 & 24 \\
\hline 11 & 22 \\
\hline 23 & 21 \\
\hline 10 & 19 \\
\hline 22 & 18 \\
\hline 4 & 15 \\
\hline 2 & 13 \\
\hline 17 & 9 \\
\hline 3 & 7 \\
\hline 20 & 7 \\
\hline 18 & 6 \\
\hline 12 & 5 \\
\hline 21 & 4 \\
\hline 27 & 4 \\
\hline 28 & 4 \\
\hline 19 & 2 \\
\hline
\end{tabular}

\section{Conclusion}

Offshore renewable energies, such as offshore wind, are becoming a new technology to develop a better green world.

Its growth is associated to the use of port facilities, where the offshore wind farms can be stored or pre-installed.

The objective of this paper was to study the storage space availability for ports in terms of being used for the new offshore wind industry. 
The case of study has analysed the port facilities in Spain, country with a great offshore wind resource in some specific locations.

Results indicate that the ports of Huelva, Barcelona, Sevilla and Valencia are the most adequate in terms of storage space availability for developing offshore wind. However, it is important for future research analysing if these ports are close to shipyards and if they are located in areas with a great offshore wind resource.

This paper is important in order to carry out a roadmap of the offshore wind sector in Spain, which can repair the economic and social damaged due to SARS-CoV-2 pandemic.

\section{Acknowledgement}

This research was funded by Project PID2019105386RA-I00 "Design of a tool for the selection of offshore renewable energy locations and technologies: application to Spanish territorial waters (SEARENEW)", financed by Ministerio de Ciencia e Innovación - Agencia Estatal de Investigación/10.13039/501100011033.

\section{References}

[1] W.D. Nordhaus, J.G. Boyer, Requiem for Kyoto: An economic analysis of the Kyoto protocol, Energy J. 20 (1999) 93-130. doi:10.5547/issn0195-6574-ej-vol20nosi-5.

[2] T. Herzog, World Greenhouse Gas Emissions in 2005, 2009.

[3] C. Kennedy, J. Steinberger, B. Gasson, Y. Hansen, T. Hillman, M. Havránek, et al., Greenhouse gas emissions from global cities, Environ. Sci. Technol. 43 (2009) 7297-7302. doi:10.1021/es900213p.

[4] United Nations Framework Convention on Climate Change, Paris Agreement, Paris (France), 2015. http://unfccc.int/files/meetings/paris_nov_2015/applicati on/pdf/paris_agreement_english_pdf.

[5] B. Sørensen, A history of renewable energy technology, Energy Policy. 19 (1991) 8-12. doi:10.1016/03014215(91)90072-V.

[6] International Renewable Energy Agency, (n.d.).

[7] IEA, Energy and Climate Change, 2015. doi:https://doi.org/10.1115/1.2018-DEC-2.

[8] G.M. Joselin Herbert, S. Iniyan, E. Sreevalsan, S. Rajapandian, A review of wind energy technologies, Renew. Sustain. Energy Rev. 11 (2007) 1117-1145. doi:10.1016/j.rser.2005.08.004.

[9] El primer parque eólico del mundo fue Towards 2000 Renovables Verdes, (n.d.).

[10] J. Winters, Z. Saunders, The Largest Wind Turbine Ever, ASME. Mech. Eng. 140 (2018). doi:https://doi.org/10.1115/1.2018-DEC-2.

[11] L. Castro-Santos, M.I. Lamas-Galdo, A. Filgueira-
Vizoso, Managing the oceans: Site selection of a floating offshore wind farm based on GIS spatial analysis, Mar. Policy. 113 (2020). doi:10.1016/j.marpol.2019.103803.

[12] L. Castro-Santos, D. Silva, A.R. Bento, N. Salvação, C. Guedes Soares, Economic feasibility ofwave energy farms in Portugal, Energies. 11 (2018) 1-16. doi:10.3390/en11113149.

[13] L. Castro-Santos, E. Martins, C. Guedes Soares, Economic comparison of technological alternatives to harness offshore wind and wave energies, Energy. 140 (2017) 1121-1130. doi:10.1016/j.energy.2017.08.103.

[14] C.A. Irawan, X. Song, D. Jones, N. Akbari, Layout optimisation for an installation port of an offshore wind farm, Eur. J. Oper. Res. 259 (2017) 67-83. doi:10.1016/j.ejor.2016.09.032.

[15] N. Akbari, C.A. Irawan, D.F. Jones, D. Menachof, A multi-criteria port suitability assessment for developments in the offshore wind industry, Renew. Energy. 102 (2017) 118-133.

doi:10.1016/j.renene.2016.10.035.

[16] Puertos del Estado, Puertos del Estado, Spain, 2020.

[17] Puertos del Estado, Estadísticas. Puertos del Estado, (2016). http://www.puertos.es/eses/oceanografia/Paginas/portus.aspx (accessed May 3, 2019).

[18] M. y A.U. Ministerio de Transportese, Memorias anuales 2018, (2021).

http://www.puertos.es/Memorias_Anuales/2018/mapa. html (accessed February 26, 2021). 